\title{
Profits from Pollutants: Economic Feasibility of Integrated Anaerobic Digester and Nutrient Management Systems
}

\author{
Gregory M. Astill \\ C. Richard Shumway
}

\begin{abstract}
There has been sustained interest from both environmental regulators and livestock associations to expand the use of anaerobic digester (AD) technology to mitigate greenhouse gas emissions. However, the generally profitable practice of codigesting off-farm organic waste could increase nitrogen and phosphorus content to the farm and exacerbate nutrient over-application concerns near large animal operations. We examine the economic feasibility of a broad set of dairy waste management systems composed of two technology groups that mitigate air and water pollution: an AD system that includes either animal waste input or combination animal/off-farm organic waste codigestion input and either compressed natural gas (CNG) or combined heat and power (CHP) output; and a filtration system that includes fiber separation, nutrient separation, and/or water recovery. We conclude that $\mathrm{AD}$ setups without codigestion are only economically feasible under limited conditions, but scenarios which use codigestion have the potential to contribute to nutrient over-application without nutrient separation technology. Trends for CNG and CHP match closely. Net present value (NPV) is greatest for AD with CNG scenarios. Estimated NPV for $\mathrm{AD}$ with $\mathrm{CNG}$ and environmental credits is $\$ 1.8$ million and $\$ 39.7$ million for dairies with 1,600 and 15,000 wet cow equivalents, respectively. For these firm sizes, the addition of codigestion contributes $\$ 4.8$ million and $\$ 47.3$ million, respectively, to estimated NPV. Nutrient separation and water recovery both lead to decreases in scenario NPV with codigestion, but with the right policies, dairy owners may be willing to adopt $\mathrm{AD}$ with nutrient separation.
\end{abstract}

Keywords: Anaerobic digestion; Codigestion; Dairy; Waste management; Nutrient management; Economic feasibility

Gregory M. Astill is an agricultural economist with the Economic Research Service, U.S. Department of Agriculture, and a former graduate research assistant in the School of Economic Sciences, Washington State University: gregory.astill@ers.usda.gov. C. Richard Shumway is a regents professor in the School of Economic Sciences, Washington State University: shumway@wsu.edu. The authors thank the anonymous journal reviewers as well as Ana Espinola-Arredondo, Phil Wandschneider, Craig Frear, and Miaoru Liu for helpful comments on earlier drafts of this article. They also thank Peter Weisberg of The Climate Trust and Kyle Juergens and Eric Powell of Regenis for providing data for this research. This research was supported by funding through award \#2012-6800219814 from the USDA National Institute for Food and Agriculture, by the Washington Agricultural Research Center, and by the USDA National Institute for Food and Agriculture, Hatch grant WPN000275. The views expressed are the authors and do not necessarily reflect those of the Economic Research Service or the USDA. 


\section{Introduction}

Environmental regulators maintain concerns about greenhouse gas (GHG) emissions and water pollution from nitrogen and phosphorus caused by waste management in large-scale animal agriculture. The UN Food and Agricultural Organization (Gerber et al. 2013) reports that milk production accounts for 2.9 percent of worldwide anthropogenic greenhouse gas (GHG) emissions. GHG emissions include methane $\left(\mathrm{CH}_{4}\right)$ and nitrous oxide $\left(\mathrm{N}_{2} \mathrm{O}\right)$. They cite the following as potentially highly effective mitigating technologies: $\mathrm{AD}$ for both $\mathrm{CH}_{4}$ and $\mathrm{N}_{2} \mathrm{O}$, fiber separation for $\mathrm{CH}_{4}$, and consideration of soil nutrient balance before manure application and timing of manure application for $\mathrm{N}_{2} \mathrm{O}$. Smith et al. (2007) find similar results. They estimate that $\mathrm{CH}_{4}$ from all livestock contributes 4.6 - 5.5 percent of world $\mathrm{GHG}$ emissions while nutrient application in crop production contributes $5.4-6.5$ percent of world GHG emissions.

The Environmental Protection Agency's (EPA) (2014a) inventory of US GHG emissions found that agriculture contributed 8.1 percent of total carbon dioxide $\left(\mathrm{CO}_{2}\right)$ equivalent emissions during the past decade. Soil management, enteric fermentation by ruminant cattle, and manure management contributed 4.7 percent, 2.2 percent and 1.1 percent of total US emissions, respectively. Enteric fermentation and manure management are the first and fourth largest contributors to $\mathrm{CH}_{4}$ emissions and contribute 24.9 percent and 9.3 percent of total $\mathrm{US} \mathrm{CH}_{4}$ emissions, respectively. Methane emissions increased 68 percent from 1990 to 2012 due to increasing use of liquid systems of dairy and swine manure storage and management.

Water pollution occurs most frequently through the over-application of nutrients on agricultural land. The EPA (2014b) reports that nutrients are the second and third largest causes of impairment of bodies of water and waterways, respectively, and agriculture is the third and first largest source of impairment of bodies of water and waterways, respectively. Harms 
attributed to current nutrient management practices on US dairies include $\mathrm{P}$ and $\mathrm{N}$ eutrophication in US waterways (Kiely 1997; Van Breeman and Van Dijk 1988), the loss of 70 percent of manure $\mathrm{N}$ through ammonia volatilization (Council for Agricultural Science and Technology 2002), the creation of harmful particulate matter through ammonia reactions (Erisman and Schaap 2004), and blue baby syndrome and reproductive harm in humans from nitrate accumulation in the water supply (Washington State Department of Health 2005).

Ribaudo et al. (2003) found that US dairy farms on average produced 22 percent more $\mathrm{N}$ and 34 percent more $\mathrm{P}$ in manure than could be applied to the dairies' available cropland at agronomic rates. Without enforced regulation, Innes (2000) concludes that, when manure transport cost is high, producers will apply nutrients to near fields even if they exceed agronomic requirements. ${ }^{1}$ Sanford, Posner and Hadley (2009) find a viable transport distance of only 3.2 to $7.6 \mathrm{~km}$ for dairy manure slurry as a fertilizer product for corn. In addition to over-application of nutrients, failure to incorporate manure into the soil can lead to further N pollutants (Rotz 2004). Regulators are increasingly enforcing environmental regulations on dairy producers to reduce over-application of nutrients (Schmit and Knoblauch 1995; Zhang and Parsons 2001; Huang, Magleby and Christensen 2005).

An anaerobic digester (AD) is an enclosed vessel that allows anaerobic bacteria to break down volatile solids in organic waste and convert them to biogas. A variety AD designs exist (Wilkinson 2011a). AD technology has been used on large livestock operations in the US and Europe for nearly 50 years as a way to mitigate GHG emissions (Ibid.) — and to lesser extent

\footnotetext{
${ }^{1}$ The agronomic rate of $\mathrm{N}$ is the amount applied to maximize plant growth and minimize excess $\mathrm{N}$ percolating beyond the root zone into the groundwater (Natural Resources Conservation Service 2011, p.503-68).
} 
odor (Wright et al. 2004, AgSTAR 2011). ${ }^{2}$ For an overview of the history, engineering, chemistry and economics of agricultural AD, see Wilkinson (2011a). AD technology has also been widely used in municipal wastewater treatment in the US and the UK (Water Environment Federation 2015, Sadhukhan 2014). Biogas capture, a similar technology, has been widely used by US landfills (EPA 2016). For a review of the variety of uses of AD including treatment of municipal solid waste, municipal wastewater, and agricultural waste see Appels et al. (2011).

The use of AD technology in agriculture varies throughout the world. Lebuhn, Munk, and Effenberger (2014) report that more than 7 million household-size anaerobic digersters are used for inexpensive cooking fuel in China and more than 1 million in India. Germany has over 7,700 larger scale, farm level digesters. Use of AD technology in the US has lagged well behind Germany, but adoption rates have increased in recent years. Of the 209 anaerobic digersters on dairies in the US, 176 have been built since 2005 (AgSTAR 2016). Combined, these farm projects reduce methane emissions by 2.41 million metric tons of $\mathrm{CO}_{2}$ equivalent $\left(\mathrm{tCO}_{2} \mathrm{e}\right)$ per year (Ibid.). AgSTAR (2011) estimates that there are another 2,645 US dairy farms that are likely candidates for $\mathrm{AD}$ adoption with a potential to reduce methane emissions by nearly 1.8 million tons per year or 41 million ton $\mathrm{CO}_{2}$ equivalent per year.

The biggest factors affecting the adoption of AD technology are environmental penalties and incentives, high initial capital costs, and sale price of $\mathrm{AD}$ coproducts. $\mathrm{AD}$ tends to favor larger operations (Leuer, Hyde and Richard 2008). Due to their potential to generate jobs in rural areas and reduce environmental harm, many of the ADs built in the US have been funded in part by government grants through programs like the Rural Energy for America Program, the

\footnotetext{
${ }^{2}$ Glover (1996) refers to a lawsuit brought against a US livestock producer in which it was determined that the producer was a source of unbearable odor for neighbors and required payment to the plaintiffs of \$500/day for each "smelly" day and \$100/day for all other days. Palmquist, Roka and Vukina (1997) estimate that rural residences near US swine operations lost 9 percent of their value.
} 
Conservation Innovation Grants program, and the Environmental Quality Improvement Program. Grants have a large impact on the economic feasibility of AD projects, and most projects undertaken in the US have used grants to defray part of the initial capital expense (Cowley 2014). Germany has seen widespread $\mathrm{AD}$ adoption in agriculture through the use of price guarantees (Lebuhn, Munk, and Effenberger 2014). Funding assistance programs for AD have been recommended as cost-effective policy instruments for reducing GHG emissions from livestock operations (Njuki and Bravo-Ureta 2015).

Recent economic research indicates that anaerobic digesters may be economically viable in the US, but only with some combination of codigestion, fiber separation, capital cost subsidies, and/or environmental credits (Bishop and Shumway 2009; ECOregon 2010; Key and Sneeringer 2012, Camarillo et al. 2012; Klavon et al. 2013; Manning and Hadrich 2015). Codigestion is profitable for $\mathrm{AD}$ operators due to tipping fees for taking organic waste and the additional methane produced by digestion. Food waste from restaurants or food processing plants is the most common organic waste codigested with on-farm animal waste. ${ }^{3}$ In order to divert recyclable materials, some US states (e.g., Connecticut, Vermont, Massachusetts, California, and Rhode Island) and cities (e.g., New York City and Seattle) have placed bans or mandates on disposing commercial food waste in landfills (Henricks 2014; US Composting Council 2014; Executive Office of Energy and Environmental Affairs of the Commonwealth of Massachusetts 2015). Bans and mandates would greatly increase the demand for food waste disposal through ADs.

Food waste generally contains much higher amounts of volatile solids than animal waste and leads to disproportionately larger amounts of methane generated per volume digested

\footnotetext{
${ }^{3}$ Other research examines the use of a biorefinery to produce chemicals from food waste either independently (Matharu et al. 2016) or in conjunction with $\mathrm{AD}$ (Sadhukhan et al. 2016).
} 
(Lisboa and Lansing 2013). Higher methane output directly impacts the amount of electricity or natural gas generated by the AD. Additionally, methane capture from organic wastes qualify for many of the same environmental credits as methane capture from animal wastes, although at a lesser rate. Typically the AD owner will be paid a tipping fee for accepting the waste which generates additional income.

Codigestion of off-farm organics can greatly increase the economic value of an $\mathrm{AD}$, but there is evidence that acceptance of certain forms of off-farm organic waste could increase nitrogen and phosphorous content to the farm (Atandi and Rahman 2012). Thus, codigestion mitigates GHG emissions by making AD technology more economically viable, but likely exacerbates nutrient over-application and water pollution. Integrating nutrient separation technologies with ADs that practice codigestion has the potential to mitigate both GHG emissions and water pollution. Life cycle assessment has been used extensively to estimate the environmental value of GHG reduction by AD (Sadhukhan 2014) or nutrient separation in municipal wastewater treatment (Piao et al. 2016; Niero et al. 2014; Corominas et al. 2013; and Ontiveros and Campanella 2013). Environmental value may not be attained, however, if economic incentives are not aligned.

We examine the economic feasibility of a broad set of dairy waste management systems composed of two technology groups that mitigate air and water pollution: an AD system that includes either animal waste input or combination animal/off-farm organic waste codigestion input and either CNG or CHP output; and a filtration system that includes fiber separation, nutrient separation, and/or water recovery. A graphical representation of the components is presented in Figure 1. 
The two technology groups interconnect through their capture of methane and nutrients. This paper contributes to the literature by assessing the economic feasibility of technology combinations using methane and nutrient generation and utilization functions developed by AD engineers in order to structurally model complementary effects of GHG and water pollution mitigation.

Figure 1. Effluent flows to AD system components

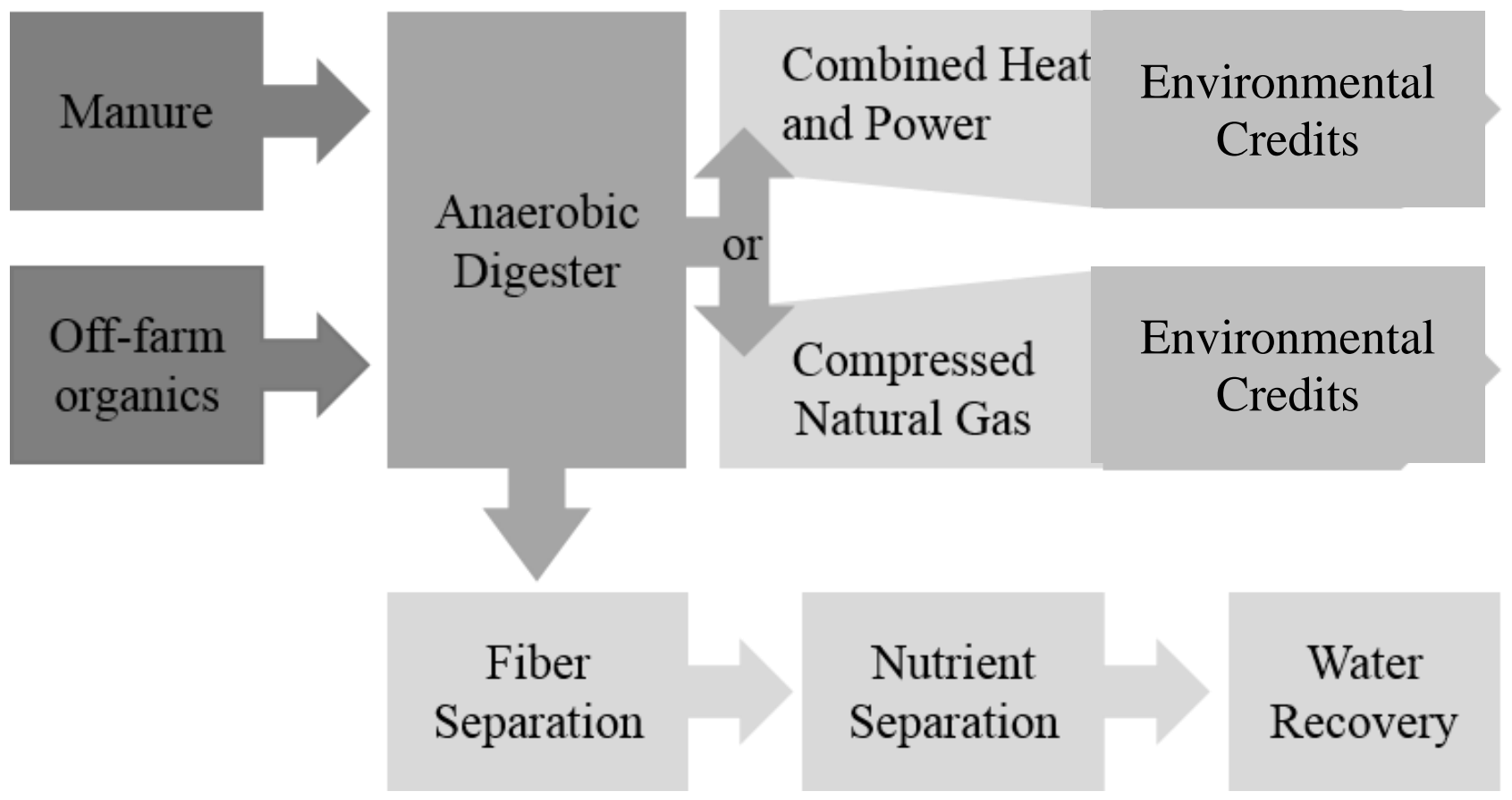

If the $\mathrm{AD}$-generated methane is sold as compressed natural gas, it must be scrubbed of water and other contaminants before compressing it for delivery or use (Najafpour et al. 2006; Sadhukhan et al. 2014; Sadhukhan et al. 2010a; Sadhukhan et al. 2010b; Sadhukhan et al. 2009). Storage of compressed gasses is costly, so most AD owners in the US who produce CNG establish a connection to a national CNG pipeline where all of their production is immediately accepted and metered. Connection fees to a natural gas pipeline can be quite costly. Pipeline connection fees are primarily determined by the distance to existing pipeline infrastructure and thus can vary widely from site to site (Murray, Galik and Vegh 2014). 
In the US it is more common for methane to be used in combined heat and power generation. In CHP a combustion engine and electric generator (typically called a genset) produce electricity while a heat exchanger captures excess heat from the engine. Unless the dairy needs all the electricity provided by the CHP, interconnection fees are required to sell electricity on the municipal grid. Interconnection fees vary widely depending on local conditions. When comparing the investment value of CNG to CHP, not only are the prices of natural gas and electricity important, but also the value of environmental credits that derive from each product.

A number of governments have introduced policies to reduce carbon emissions. Policies include carbon taxes in Norway, Sweden, Denmark, and Finland introduced in the 1990's, the European Union Emission Trading Scheme enacted in 2005, the tradable carbon performance standard enacted in Alberta, Canada in 2007, the revenue-neutral carbon tax in British Columbia Canada and the emissions trading scheme in New Zealand enacted in 2008, the Regional Greenhouse Gas Initiative's (RGGI) downstream cap-and-trade (emissions trading) program for electric power generators in the northeast United States initiated in 2009 (Aldy and Stavins 2012), and the most recognized environmental market currently operating in the US - the California mandatory GHG emissions reporting and cap-and-trade program which began in 2013 and allows trading in both carbon allowances and carbon offsets. Carbon offset prices in the California market averaged $\$ 12.75$ per metric ton $\mathrm{CO}_{2}$ equivalent in 2014 and the first half of 2015 (California Carbon Dashboard 2015).

Influenced by the success of the British Columbia carbon tax, the group Carbon Washington (2015) has introduced a 2016 voter initiative on the Washington State ballot to impose a revenue-neutral $\$ 25$ per metric ton of $\mathrm{CO}_{2}$ tax on fossil fuels in the state. If approved, carbon tax receipts will be offset by reductions in state sales and business tax rates. The enacted 
policies have been credited with inducing substantial reduction in GHG emissions (e.g., Elgie and McClay 2013; RGGI 2014). It is likely that environmental markets will become more prominent as concern about climate change increases.

Environmental incentives have contributed substantially to the adoption of AD technology in Europe. Germany introduced a feed-in tariff in 1991 which induced utilities to purchase renewable energy at a subsidized price. The tariff is widely credited as being the primary cause behind Germany's widespread adoption of ADs (Wilkinson 2011b) from 140 in 1992 to 7,720 at the end of 2013 (Lebuhn, Munk, and Effenberger 2014). However, there is some evidence that the incentive structures implemented by the German government to encourage $\mathrm{AD}$ adoption have led to market distortions. ${ }^{4}$

The effect of developing carbon markets on US AD adoption could be large (Gloy 2011). AD owners in the US who produce renewable natural gas can receive RINs and LCFS credits. RINs are available nationally as a credit managed by the EPA. LCFS credits are available for CNG sold as transportation fuel in California and can be used in combination with RINs. The first half of 2013 saw an average LCFS price of \$45/credit (or \$4.01/MMBTU; Argus Media 2014). AD owners in the US who produce renewable electricity can receive carbon credits, RECs, and tax credits. Utility companies offer RECs under state government mandate to generate a certain proportion of renewable energy. In some states where mandates are strict, RECs can be highly priced (Informa Economics 2013). Also, some state governments offer tax credits to producers of renewable electricity.

\footnotetext{
${ }^{4}$ In 2013 the German Agency for Renewable Resources (FNR) reported that nearly 10 percent of German agricultural land was used to grow crops destined for biogas generation (Lebuhn, Munk, and Effenberger 2014). Osterburg and Röder (2013) found that conversion of grassland to biogas fuel crops has occurred in environmentally sensitive areas, and Britz and Delzeit (2013) concluded that German government incentives for biogas production are capable of impacting global agricultural markets, prices, quantities and land use.
} 
Nutrients are processed by three technologies that build on one another: fiber separation, nutrient separation, and water recovery. Fiber separation mechanisms are commonly used with ADs. Fiber separation can be implemented on farms without ADs (Van Horn et al. 1994), but the fiber is commonly composted before it is used as bedding. ${ }^{5}$ A 1997 survey (Meyer, Garnett and Guthrie) of 1840 California dairies indicated that 14 percent used mechanical solid separators and 39 percent used settling ponds to separate fiber from liquid waste.

Using separated fiber as bedding material contributes significant cost savings to dairies, but there is potential for even more gain if markets continue to develop for using digested fiber as peat moss replacement. A line of $\mathrm{AD}$ fiber product has recently been introduced as peat moss replacement in stores like Wal-Mart (The Prasino Group and Innovation Center for US Dairy 2014).

After fiber has been removed from waste effluent, various nutrient separation technologies are able to remove $\mathrm{N}$ and P. Coppedge et al. (2012) assess three nutrient separation technologies and conclude that (a) P solids separation is cost effective to reduce excess $\mathrm{P}$ application but fails to affect $\mathrm{N}$ levels, (b) struvite crystallization incurs high operating costs for nutrient separation and is economically non-viable, and (c) combined P solids separation and ammonium sulfate separation is high cost but also effective in removing both $\mathrm{P}$ and $\mathrm{N}$. Thus, we consider P separation and ammonium sulfate separation in the nutrient separation component.

\footnotetext{
${ }^{5}$ Digested fiber has far fewer pathogens than undigested fiber. However, there is some evidence that pathogen content of the bedding material may not be as important in the prevention of infections like mastitis as simply keeping animal stalls free of fresh manure and urine (Schwarz, Bonhotal and Staehr 2010).
} 
Membrane-based water recovery systems can remove an even larger amount of $\mathrm{P}$ and $\mathrm{N}$ from the wastewater along with potassium and other dissolved salts. ${ }^{6}$ Water recovery requires effluent to be pretreated using $\mathrm{P}$ solids separation. Pretreating with ammonium sulfate separation would be redundant to the capabilities of the water recovery system (Chiumenti et al. 2013).

Output from a water recovery system would provide the remaining nutrients in a concentrate and clean water in a permeate. Depending on the method and extent of filtration, water could be used to flush stalls or even be used as drinking water for livestock.

Water recovery systems are capital intensive and incur large operating costs because of chemical use. However, the potential benefits in terms of nutrient management are large. They include prevention of nutrient over-application, nutrient run-off, and salt buildup in soils. They can also offset water costs and provide revenue from organically certifiable nutrient sales.

\section{Methods}

This paper estimates the NPV for a variety of waste management technology combinations for different sized dairies focusing on the potential to concurrently mitigate GHG emissions and water pollution. We examine dairies with 1,600, 4,500, and 15,000 head to provide insight into scale economies. In 2012, there were 1,231 dairies in the US with herd sizes of 1,000 to 2,499 and 576 dairies with herd sizes of 2,500 or more (U.S. Department of Agriculture, National Agricultural Statistics Service (NASS) 2012). Our data provides capital and operating costs for dairies close to these three sizes and allows us to account for scale economies in all technologies except for water recovery. When data does not conform directly to those sizes, we use linear approximations between the two nearest data points.

\footnotetext{
${ }^{6}$ Current research focuses on trapping small, suspended, and dissolved particles behind a semi-permeable membrane as the fluid is pushed through, most commonly via a pressure gradient (Ma et al. 2013a). The three most common membrane systems being researched are microfiltration, ultrafiltration, and reverse osmosis (ibid.)
} 
Due to the emergent nature of some of the technologies, survey data of established operations is unavailable or very limited. AD, off-farm organic waste intake, CNG, CHP, environmental REC and tax credits, fiber separation, nutrient separation, and water recovery data were gathered from previous research and from industry partners. They pertain to Washington State. Environmental carbon credits and RINs apply at the national level, while LCFS credits pertain to California and nearby states. All monetary values were adjusted to 2013 values using the Chemical Engineering Price of Construction Indices (CEPCI) for capital infrastructure and CPI for operating costs and output prices. Values are annual unless otherwise noted.

We use a four percent real discount rate calculated using Moody's Baa corporate bond yield over all maturities (Federal Reserve Economics Data 2016) less the rate of inflation given by the CPI (Shiller 2015) over the period 1919-2013. Net present values, internal rate of return (IRR), and modified internal rate of return (MIRR) are estimated using a capital lifetime of 20 years. For the calculation of MIRR we use a 7 percent capital reinvestment discount rate (Coppedge et al. 2012). Calculations are straightforward in many scenarios, but methane and nutrient functions have impacts on cost and revenue values when certain technology components are used concurrently. All calculations are carried out in the Anaerobic Digester System Enterprise Budget Calculator developed in tandem with this research paper and available for download. ${ }^{7}$ All disaggregated values not reported in this paper are accessible in the enterprise budget calculator.

The model uses functions developed by AD engineers to model methane and nutrient generation and utilization among the technology components. Methane production is a function of volatile solids (VS) and methane conversion ability of those solids, shown in Table 1 using

\footnotetext{
7 The Anaerobic Digester System Enterprise Budget Calculator can be downloaded from http://csanr.wsu.edu/anaerobic-digestion-systems/enterprise-budget-calculator/.
} 
parameters typical for dairy scrape manure and within the normal range for food wastes used as codigestants. $^{8}$

Table 1. Methane conversion

\begin{tabular}{lll}
\hline Model Parameters & Volume & Unit \\
\hline Influent from animal waste $^{\mathrm{a}}$ & 0.117 & $\mathrm{~m} 3 / \mathrm{WCE} / \mathrm{day}$ \\
Influent from codigestant $^{\mathrm{b}}$ & 0.02229 & $\mathrm{~m} 3 / \mathrm{WCE} / \mathrm{day}$ \\
Total influent & 0.13929 & $\mathrm{~m} 3 / \mathrm{WCE} / \mathrm{day}$ \\
Methane from animal waste $^{\mathrm{c}}$ & 1.56078 & $\mathrm{~m} 3 \mathrm{CH} / \mathrm{WCE} / \mathrm{day}$ \\
Methane from codigestant $^{\mathrm{d}}$ & 1.34735 & $\mathrm{~m} 3 \mathrm{CH} / \mathrm{WCE} / \mathrm{day}$ \\
Total methane & 2.90813 & $\mathrm{~m} 3 \mathrm{CH}$ /WCE/day \\
\hline
\end{tabular}

a. $0.13 \mathrm{~m} 3 / \mathrm{WCE} / \mathrm{day} * 90 \%$ enters digester (Frear 2015)

b. $16 \%$ total influent due to codigestant $* 0.117 \mathrm{~m} 3 /$ day animal waste influent / $84 \%$ total influent due to animal waste (Braun, Brachtl, and Grasmug 2003)

c. $58 \mathrm{~kg} \mathrm{VS} / \mathrm{m} 3$ (American Society of Agricultural Engineers 2005) * $0.23 \mathrm{~m} 3 \mathrm{CH} 4 / \mathrm{kg}$ VS (Ma et al. $2013 \mathrm{~b}) * 0.117 \mathrm{~m} 3$ influent/WCE/day

d. $163.4 \mathrm{~kg} \mathrm{VS} / \mathrm{m} 3 * 0.37 \mathrm{~m} 3 \mathrm{CH} 4 / \mathrm{kg}$ VS $* 0.02229 \mathrm{~m} 3$ influent/WCE/day (Camarillo et al. 2013)

We account for the flow of nutrients through the dairy when considering alternative scenarios by summing nutrient stream inputs and subtracting nutrient stream outputs to calculate the amount applied to fields as fertilizer. Nutrient stream components include P, N, solids, and water. Weight of nutrient stream components entering the waste management system through animal waste (which includes parlor water to dilute manure) and codigestant appear in the top portion of Table 2 . The percentages of total nutrient stream component removed by each present technology appear in the lower portion of Table 2. Remaining nutrient stream component percentages are applied to agricultural fields.

Table 2. Nutrient balances

\begin{tabular}{lllllll}
\hline Waste stream & $\mathrm{N}$ & $\mathrm{P}$ & Solids & Water & Total & Units \\
\hline Animal waste $^{\mathrm{a}}$ & 0.090 & 0.027 & 3.104 & 20.653 & 23.874 & $\mathrm{MT}$ \\
Parlor water $^{\mathrm{a}}$ & 0.014 & 0.003 & 0.219 & 23.688 & 23.924 & $\mathrm{MT}$ \\
Off-farm organics $^{\mathrm{b}}$ & 0.100 & 0.010 & 0.000 & 6.588 & 6.698 & $\mathrm{MT}$
\end{tabular}

\footnotetext{
${ }^{8}$ Scrape manure is heavily diluted before use in the digester. We use 63 percent dilution of raw manure to simulate the VS concentration of scrape manure influent.
} 


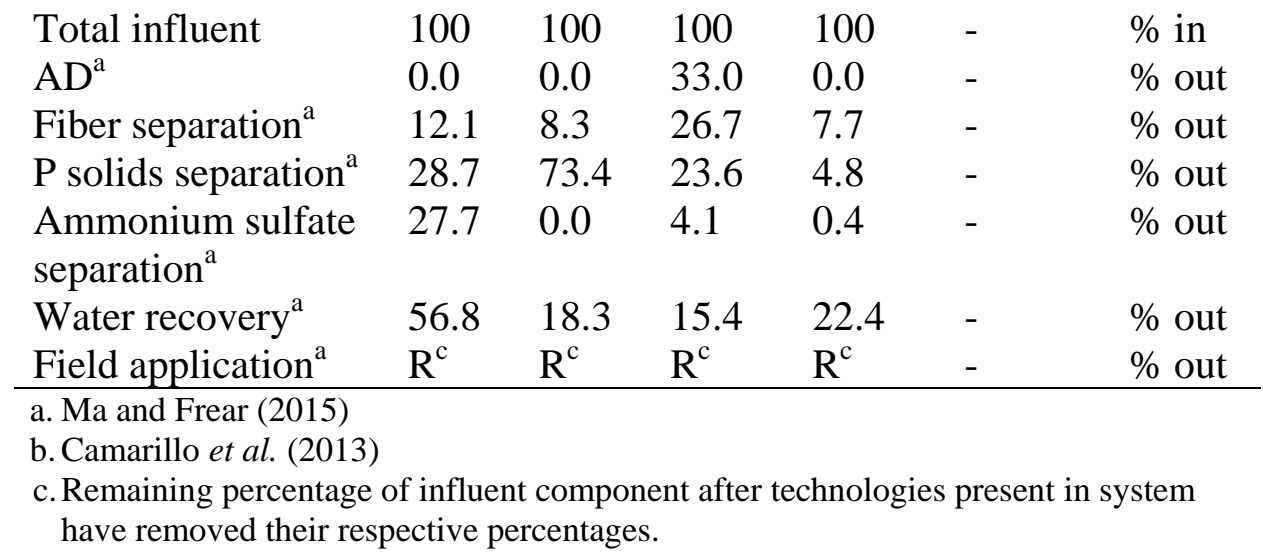

Table 3. Capital cost by technology component, herd size, and codigestion $(\$ 1,000 s)$

\begin{tabular}{llrrrrrr}
\hline Acronym & Component & \multicolumn{3}{c}{$\begin{array}{c}\text { Capital cost for herd size } \\
\text { (WCE) }\end{array}$} & \multicolumn{4}{c}{ Codigestion addition for } \\
& & 1,600 & 4,500 & 15,000 & 1,600 & 4,500 & 15,000 \\
\hline AD & Anaerobic digester $^{\mathrm{a}}$ & $\$ 1,879$ & $\$ 3,210$ & $\$ 9,648$ & $\$ 355$ & $\$ 587$ & $\$ 1,646$ \\
$\mathrm{CNG}$ & Compressed natural gas $^{\mathrm{b}}$ & $\$ 1,718$ & $\$ 2,463$ & $\$ 5,160$ & $\$ 443$ & $\$ 1,246$ & $\$ 4,153$ \\
$\mathrm{CHP}$ & Combined heat \& power $^{\mathrm{c}}$ & $\$ 1,103$ & $\$ 1,875$ & $\$ 4,670$ & $\$ 368$ & $\$ 1,034$ & $\$ 3,812$ \\
$\mathrm{FS}$ & Fiber separation $^{\mathrm{d}}$ & $\$ 63$ & $\$ 176$ & $\$ 588$ & $\$ 0$ & $\$ 0$ & $\$ 0$ \\
$\mathrm{NS}$ & Nutrient separation $^{\mathrm{e}}$ & $\$ 691$ & $\$ 1,913$ & $\$ 6,338$ & $\$ 107$ & $\$ 301$ & $\$ 1,005$ \\
$\mathrm{WR}$ & Water recovery $^{\mathrm{f}}$ & $\$ 2,265$ & $\$ 6,339$ & $\$ 21,092$ & $\$ 322$ & $\$ 907$ & $\$ 3,023$ \\
\hline
\end{tabular}

a. Cost includes freight, excavation, vessel, insulation, roof, piping, equipment, permitting \& engineering and system start-up. Cost of codigestion includes pre-digestion mixing pit and AD volume increase. Cost by size is a linear approximation between data points at 1,600,2,500, and 15,000 WCE dairies using combinations of AD and codigestion (Juergens and Powell 2014).

b. Cost includes gas cleaning equipment, construction, installation, spare parts, pipeline injection point, transportation to pipeline, design allowance, sales tax, contingency, and project management. Cost by size is a product of reported average cost for a 5,000 WCE dairy with CNG (Coppedge et al. 2012).

c. Cost includes mechanical building, generators, switchgear connections, gas cooling, electrical, utility interconnection. Cost by size is a linear approximation between data points at 4,500 and 15,000 WCE dairies using CHP (Juergens and Powell 2014).

d. Cost includes liquid solid separator. Cost by size is a product of reported average cost per WCE (Ma et al. 2013b).

e. Cost includes dissolved air filtration (DAF) P solids separation equipment and construction (Yorgey et al. 2015) and ammonium sulfate separation equipment and construction (Promus Energy 2014; excludes crystallizer, drier, and/or pelletizer), and building (Painter and Gray 2012). Cost by size is a product of reported average cost per WCE.

f. Cost includes ultrafiltration and reverse osmosis equipment and construction (Ma et al. 2013a) and building (Painter and Gray 2012). Cost by size is a product of reported average cost per WCE of aggregate fiber separation, P solids separation, and ultrafiltration-and-reverse-osmosis system net of fiber separation and $\mathrm{P}$ solids separation costs. 
In Table 3, the AD capital costs are nearly \$1.9 million for a 1,600 WCE dairy and \$9.6 million for a 15,000 WCE dairy. Capital costs for compressed natural gas are greater than for CHP - the former costs 53-91 percent as much as the AD while the latter costs 48-59 percent as much. At the 1,600 WCE and 15,000 WCE sizes respectively, fiber separation is the least expensive capital component at 3-6 percent the cost of AD, while nutrient separation capital costs are 37-66 percent as much as the AD, and water recovery capital costs are 121-219 percent as much as the AD.

Codigesting 16 percent of $\mathrm{AD}$ volume using off-farm organic waste increases capital costs by 14-19 percent for $\mathrm{AD}$, nutrient separation, and water recovery. It does not add any capital cost for fiber separation, and it adds 26-82 percent to the capital cost for CNG and CHP. We assume off-farm organics to have little fiber content, and thus fiber separation faces little additional material to process. Costs for both CNG and CHP are based on the amount of methane produced, and off-farm organic waste is estimated from Table 1 to generate 86 percent more methane than animal waste which greatly expands the capacity requirements for these components.

Table 4. Annual operating cost by technology component, herd size, and codigestion $(\$ 1,000 s)$ Acronym Component Operating cost for herd size Codigestion addition for

\begin{tabular}{llrrrrrr} 
& & \multicolumn{3}{c}{ (WCE) } & \multicolumn{3}{c}{ herd size (WCE) $^{2}$} \\
& & 1,600 & 4,500 & 15,000 & 1,600 & 4,500 & 15,000 \\
\hline AD & Anaerobic digester $^{\mathrm{a}}$ & $\$ 41$ & $\$ 116$ & $\$ 386$ & $\$ 8$ & $\$ 22$ & $\$ 74$ \\
CNG & Compressed natural gas $^{\mathrm{b}}$ & $\$ 61$ & $\$ 103$ & $\$ 256$ & $\$ 25$ & $\$ 71$ & $\$ 235$ \\
CNGEC & CNG environmental credits $^{\mathrm{c}}$ & $\$ 47$ & $\$ 132$ & $\$ 440$ & $\$ 14$ & $\$ 39$ & $\$ 131$ \\
$\mathrm{CHP}$ & Combined heat \& power $^{\mathrm{d}}$ & $\$ 113$ & $\$ 313$ & $\$ 917$ & $\$ 18$ & $\$ 50$ & $\$ 147$ \\
$\mathrm{CHPEC}$ & CHP environmental credits $^{\mathrm{e}}$ & $\$ 6$ & $\$ 8$ & $\$ 13$ & $\$ 1$ & $\$ 3$ & $\$ 9$ \\
FS & Fiber separation $^{\mathrm{f}}$ & $\$ 10$ & $\$ 28$ & $\$ 95$ & $\$ 0$ & $\$ 0$ & $\$ 0$ \\
NS & Nutrient separation $^{\mathrm{g}}$ & $\$ 158$ & $\$ 444$ & $\$ 1,480$ & $\$ 23$ & $\$ 64$ & $\$ 213$ \\
WR & Water recovery $^{\text {h }}$ & $\$ 1,027$ & $\$ 2,886$ & $\$ 9,620$ & $\$ 172$ & $\$ 482$ & $\$ 1,608$ \\
\hline
\end{tabular}

a. Cost consists of operation and maintenance at reported average cost $-\$ 10$ per m3 volume capacity (Frear 2015).

b. Cost includes water for scrubbing, pipeline injection fees, transportation, repairs, maintenance, lubrication oil, remote monitoring, labor, and electricity at reported average cost (Coppedge et al. 2013).

c. Cost includes RIN transaction (Coppedge et al. 2012; 10 percent of RIN revenue). The same cost applies for the 
sensitivity scenario that includes LCFS credits.

d. Cost includes building, equipment, engine repairs and maintenance, systems operation, oil and filters, utilities, other professional service. Cost by size is a linear approximation between data points at 1,600, 4,500, and 15,000 WCE dairies using AD and codigestion where codigestion generates 20 percent of total methane (Juergens and Powell 2014).

e. Cost includes annual verification fee and credit issuance fee for carbon credits (Weisberg 2013). RECs have a transaction cost of 1 percent of REC revenue and no costs associated with tax credits.

f. Cost includes maintenance at reported average cost $-\$ 6.35$ per ton removed fiber (Terre-Source 2003).

g. Cost includes maintenance for P solids separation (Yorgey et al. 2015; \$0.68 per ton influent) and labor, electricity, acid, materials for ammonium sulfate separation (Promus Energy 2014).

h. Cost includes electricity (Chiumenti et al. 2013), chemicals (Halpern 2013), labor (Promus Energy 2014 using ammonium sulfate figure), and maintenance (Coppedge et al. 2012 using ammonium sulfate figure).

Fiber separation and CHP environmental credits have the least expensive annual operating costs as noted in Table 4. $\mathrm{AD}, \mathrm{CNG}$, and $\mathrm{CNG}$ environmental credits have operating costs about four to six times higher than fiber separation. CHP and nutrient separation have operating costs about 10 to 16 times higher than fiber separation. Water recovery is by far the most costly technology to operate-100 times as costly as fiber separation. The cost of chemicals comprises the largest portion of operating costs for water recovery. Codigestion contributes the least to operating costs for fiber separation and the most to operating costs for water recovery.

Table 5. Annual revenue by technology component, herd size, and codigestion $(\mathbf{\$ 1 , 0 0 0 s})$

\begin{tabular}{|c|c|c|c|c|c|c|c|}
\hline \multirow[t]{2}{*}{ Acronym } & \multirow[t]{2}{*}{ Component } & \multicolumn{3}{|c|}{$\begin{array}{l}\text { Revenue for herd size } \\
\left(\mathrm{WCE}^{\mathrm{a}}\right.\end{array}$} & \multicolumn{3}{|c|}{$\begin{array}{l}\text { Codigestion addition for } \\
\text { herd size (WCE) }\end{array}$} \\
\hline & & 1,600 & 4,500 & 15,000 & 1,600 & 4,500 & 15,000 \\
\hline $\mathrm{AD}$ & Anaerobic digester $^{b}$ & $\$ 6$ & $\$ 18$ & $\$ 59$ & $\$ 251$ & $\$ 706$ & $\$ 2,350$ \\
\hline $\mathrm{CNG}$ & Compressed natural gas ${ }^{c}$ & $\$ 68$ & $\$ 191$ & $\$ 638$ & $\$ 73$ & $\$ 206$ & $\$ 688$ \\
\hline CNGEC & CNG environmental credits ${ }^{\mathrm{d}}$ & $\$ 469$ & $\$ 1,319$ & $\$ 4,396$ & $\$ 140$ & $\$ 393$ & $\$ 1,309$ \\
\hline CHP & Combined heat \& power ${ }^{\mathrm{e}}$ & $\$ 191$ & $\$ 536$ & $\$ 1,788$ & $\$ 165$ & $\$ 463$ & $\$ 1,543$ \\
\hline CHPEC & CHP environmental credits ${ }^{f}$ & $\$ 138$ & $\$ 387$ & $\$ 1,291$ & $\$ 103$ & $\$ 290$ & $\$ 966$ \\
\hline FS & Fiber separation $^{\mathrm{g}}$ & $\$ 223$ & $\$ 628$ & $\$ 2,094$ & $\$ 0$ & $\$ 0$ & $\$ 0$ \\
\hline NS & Nutrient separation $^{\mathrm{h}}$ & $\$ 209$ & $\$ 588$ & $\$ 1,961$ & $\$ 10$ & $\$ 29$ & $\$ 98$ \\
\hline WR & Water recovery ${ }^{\mathrm{i}}$ & $\$ 808$ & $\$ 2,274$ & $\$ 7,587$ & $\$ 69$ & $\$ 194$ & $\$ 648$ \\
\hline
\end{tabular}

a. AD, FS, NS, and WR revenues all contain cost savings from effluent not applied to fields. AD cost savings is net of the cost to apply codigestion nutrients. We model a $200 \mathrm{lbs}$. N per acre rate of application (Camberato and Nielsen 2015) following best practices by injecting (Madison et al.1995) at a cost of $\$ 13.23$ per 1,000 gallons (Plastina, Johanns, and Weets 2015). About one acre per WCE would be required for a dairy with no FS, NS, or WR. We divide required acreage into equal portions of near fields and far fields. Mean and max distance to fields are estimated using the regression on log size of dairy (Harrigan 2011) and correspond to distances to near and far fields. Hauling costs are $\$ 0.01$ per mile per ton (Missouri Department of Transportation 2008).

b. AD codigestion revenue consists of tipping fees (Frear 2015; $\$ 25 /$ ton of food waste with the density of water).

c. Revenue consists of scrubbed methane (52\% volume of pre-scrubbed methane for AD with no codigestion or 58\% volume for $\mathrm{AD}$ with codigestion) sold at a wholesale price of $\$ 3.87$ per MMBTU (Coppedge et al. 2012). 
d. Revenue consists of RIN sales. RINs are generated from manure-derived methane at a rate of $0.48 \mathrm{RINs}$ per $\mathrm{m} 3 \mathrm{CH} 4$ (Coppedge et al. 2012) at a price of $\$ 1.07$ per RIN (Weisberg 2015). RINs derived from codigestant methane are generated at $80 \%$ the rate of manure-derived RINs (Weisberg 2012), and are ineligible for the more lucrative "cellulosic biofuel" EPA classification (Weisberg 2014) and are sold at the "advanced biofuel" RIN price (Weisberg 2015; \$0.46 per RIN). In the sensitivity analysis, LCFS credits are generated at a rate of 0.0892 credits per MMBTU of manure-derived methane and 0.0714 credits per MMBTU of codigestant-derived methane (variable based on feedstock) at a price of $\$ 6.45$ per MMBTU (California Air Resources Board 2015).

e. Revenue consists of electricity generated at a rate of $3.531 \mathrm{kWh}$ per $\mathrm{m} 3 \mathrm{CH} 4$ accounting for 92 percent runtime and 8 percent loss due to parasitic load. Electricity is sold at the median wholesale price from a survey of US AD owners (Cowley 2014; $\$ 0.07$ per kWh).

f. Revenue consists of carbon credits sold, RECs sold, and tax credits received. Manure-derived carbons credits are generated at a rate of 3 credits per WCE, or 0.5 credits per MT off-farm organic waste (Weisberg 2012), and are priced at $\$ 8.82$ per credit and $\$ 3.92$ per credit, respectively (Weisberg 2015). RECs are sold at a rate of $\$ 0.01$ for each $\mathrm{kWh}$ generated (Coppedge et al. 2012) for methane derived from either source. The tax credit is set to that of New York State (New York State Energy Research and Development Authority 2015; \$0.025).

g. Revenue consists of fiber generated as reported in Table 2 and sold as peat moss replacement at a price of $\$ 140.14$ per dry ton (Terre-Source 2003).

h. Revenue consists of P solids generated as reported in Table 2 and sold at a price of $\$ 88.24$ per dry ton (Promus Energy 2014). Presented here, NS is used without WR, revenue includes ammonium sulfate separation generated as reported in Table 2 and sold at a price of $\$ 98$ per ton of solution (Promus Energy 2014).

i. Revenue consists of clean water priced at $\$ 0.01$ per gallon (Coppedge et al. 2012) and liquid concentrate priced at one quarter that of concentrate ammonium sulfate (Promus Energy 2014; \$25 per ton).

Revenues increase almost linearly for each component across sizes in Table 5. Without codigestion, water recovery provides the largest revenue and is followed by CNG environmental credits. Fiber separation, nutrient separation, CHP, and CHP environmental credits produce similar revenues. NASS (2012) reports that average annual milk sale revenue in 2012 for US dairies with 1,000 to 2,499 cows was $\$ 6.3$ million and that for dairies with more than 2,500 cows was \$18.1 million. Thus, revenues from integrated AD technologies could comprise a significant portion of the operation's total revenues.

The large additional revenue from codigestion in the AD row is comprised mainly of tipping fees. Environmental credits make a large contribution to both $\mathrm{CNG}$ and $\mathrm{CHP}-689$ percent beyond CNG revenues and 72 percent beyond CHP revenue without codigestion. Avoided hauling and application costs comprise around 30 percent of water recovery revenue with small variations between sizes. Ten percent of fiber separation revenue and nine percent of 
nutrient separation revenue are from avoided hauling and application costs of manure with small variations between sizes.

Table 6. Annual net revenue by technology component, herd size, and codigestion $(\$ 1,000 s)$

\begin{tabular}{llrrrrrr}
\hline Acronym & Component & \multicolumn{3}{c}{$\begin{array}{c}\text { Net revenue for herd size } \\
\text { (WCE) }\end{array}$} & \multicolumn{4}{c}{$\begin{array}{c}\text { Codigestion addition for } \\
\text { herd size (WCE) }\end{array}$} \\
& & 1,600 & 4,500 & 15,000 & 1,600 & 4,500 & 15,000 \\
\hline AD & Anaerobic digester & $-\$ 35$ & $-\$ 98$ & $-\$ 327$ & $\$ 243$ & $\$ 684$ & $\$ 2,277$ \\
CNG & Compressed natural gas & $\$ 7$ & $\$ 88$ & $\$ 382$ & $\$ 48$ & $\$ 136$ & $\$ 453$ \\
CNGEC & CNG environmental credits & $\$ 422$ & $\$ 1,187$ & $\$ 3,956$ & $\$ 126$ & $\$ 353$ & $\$ 1,178$ \\
CHP & Combined heat \& power & $\$ 78$ & $\$ 224$ & $\$ 871$ & $\$ 147$ & $\$ 413$ & $\$ 1,397$ \\
CHPEC & CHP environmental credits & $\$ 132$ & $\$ 380$ & $\$ 1,278$ & $\$ 102$ & $\$ 287$ & $\$ 957$ \\
FS & Fiber separation & $\$ 213$ & $\$ 600$ & $\$ 1,999$ & $\$ 0$ & $\$ 0$ & $\$ 0$ \\
NS & Nutrient separation & $\$ 51$ & $\$ 144$ & $\$ 481$ & $-\$ 12$ & $-\$ 35$ & $-\$ 115$ \\
WR & Water recovery & $-\$ 219$ & $-\$ 613$ & $-\$ 2,034$ & $-\$ 103$ & $-\$ 289$ & $-\$ 960$ \\
\hline
\end{tabular}

As noted in Table 6, the largest contributors to net revenue are CNG environmental credits, fiber separation, and CHP environmental credits. Except for AD, water recovery, and the combination of codigestion with nutrient separation and with water recovery, all options generate positive net revenues. While net revenue for the $\mathrm{AD}$ by itself is negative, the $\mathrm{AD}$ would almost always be used to generate biogas whose revenue is accounted for in CNG or CHP along with their respective environmental credits. Water recovery generates large negative net revenues for all herd sizes. Net revenues for nutrient separation and water recovery are reduced at all sizes when codigestion is used because the off-farm organic waste is high in volatile solids and added water but relatively low in $\mathrm{N}$ and $\mathrm{P}$. This causes large increases in volume of effluent processed but relatively small increases in product sold. Codigestion provides large gains in AD net revenues due to tipping fees. Codigestion also leads to large gains in net revenues for CNG, CNG environmental credits, CHP, and CHP environmental credits due to increased methane output. 


\section{Results}

Not every component is required for an operational waste management system. However, some must be used in combination, and others are mutually exclusive. For example, nutrient separation cannot be implemented without fiber separation, and water recovery cannot be implemented without P solids separation. A dairy can choose between CNG and CHP and each carries unique environmental credits. Due to the nutrient and methane production functions, costs and revenues are subject to the component combination. To examine these scope effects, we calculate NPV of various component combinations for the three herd sizes in Table 7.

All NPVs increase across herd size except for three scenarios - AD with CNG, AD with $\mathrm{CHP}$, and fiber separation with nutrient separation and water recovery. Four systems dominate in expected NPV. The AD system that codigests organic waste, converts methane into $\mathrm{CNG}$, receives CNG environmental credits, and has a fiber separator achieves the highest NPV for all herd sizes. It is followed closely by the same two systems with CHP instead of CNG. In all options, receiving organics increases NPV, and converting methane into CNG results in higher NPV than conversion into CHP if environmental credits are received.

Fiber separation generates positive NPVs, nutrient separation with fiber separation generates positive but slightly smaller NPVs, and water recovery in conjunction with the other two technologies generates negative NPVs. When used in combination with AD and CNG or CHP, the NPV of each of the combined technologies is greater than the sum of the NPVs from the subtechnologies, thus providing evidence of economies of scope in technology implementation that can largely be attributed to the ability to sell digested, separated fiber at a premium.

Table 7. Twenty year NPV by scenario and herd size (WCE, \$ millions) 


\begin{tabular}{lrrr}
\hline Scenario combination & 1,600 & 4,500 & 15,000 \\
\hline AD, CNG & $-\$ 4.0$ & $-\$ 5.8$ & $-\$ 14.1$ \\
AD, CNG, CNGEC & $\$ 1.8$ & $\$ 10.3$ & $\$ 39.7$ \\
AD, CO, CNG, CNGEC & $\$ 6.6$ & $\$ 24.4$ & $\$ 87.0$ \\
FS, AD, CNG, CNGEC & $\$ 4.9$ & $\$ 19.2$ & $\$ 69.4$ \\
FS, AD, CO, CNG, CNGEC & $\$ 9.8$ & $\$ 33.3$ & $\$ 116.7$ \\
FS, NS, AD, CNG, CNGEC & $\$ 5.0$ & $\$ 19.4$ & $\$ 70.0$ \\
FS, NS, AD, CO, CNG, CNGEC & $\$ 9.6$ & $\$ 32.7$ & $\$ 114.7$ \\
FS, NS, WR, AD, CNG, CNGEC & $\$ 0.6$ & $\$ 7.3$ & $\$ 29.8$ \\
FS, NS, WR, AD, CO, CNG, CNGEC & $\$ 3.7$ & $\$ 16.4$ & $\$ 60.4$ \\
AD, CHP & $-\$ 2.4$ & $-\$ 3.4$ & $-\$ 6.9$ \\
AD, CHP, CHPEC & $-\$ 0.6$ & $\$ 1.8$ & $\$ 10.4$ \\
AD, CO, CHP, CHPEC & $\$ 5.4$ & $\$ 19.0$ & $\$ 67.9$ \\
FS, AD, CHP, CHPEC & $\$ 2.6$ & $\$ 10.7$ & $\$ 40.2$ \\
FS, AD, CO, CHP, CHPEC & $\$ 8.5$ & $\$ 27.9$ & $\$ 97.7$ \\
FS, NS, AD, CHP, CHPEC & $\$ 2.6$ & $\$ 10.8$ & $\$ 40.7$ \\
FS, NS, AD, CO, CHP, CHPEC & $\$ 8.3$ & $\$ 27.3$ & $\$ 95.6$ \\
FS, NS, WR, AD, CHP, CHPEC & $-\$ 1.7$ & $-\$ 1.3$ & $\$ 0.5$ \\
FS, NS, WR, AD, CO, CHP, CHPEC & $\$ 2.5$ & $\$ 10.9$ & $\$ 41.3$ \\
FS & $\$ 0.6$ & $\$ 1.7$ & $\$ 5.6$ \\
FS, NS & $\$ 0.6$ & $\$ 1.6$ & $\$ 5.4$ \\
FS, NS, WR & $-\$ 4.0$ & $-\$ 11.2$ & $-\$ 37.0$ \\
\hline
\end{tabular}

Notes: AD: anaerobic digester; CNG: compressed natural gas; CNGEC: CNG environmental credits; CO: codigest organics; CHP: combined heat and power; CHPEC: CHP environmental credits; FS: fiber separation; NS: nutrient separation; and WR: water recovery.

For example, consider the difference in NPV for the combined technology of fiber separation, $\mathrm{AD}, \mathrm{CNG}$, and $\mathrm{CNG}$ environmental credits with the same technology without fiber separation (i.e., the $\mathrm{AD}, \mathrm{CNG}$, and $\mathrm{CNG}$ environmental credits combined technology). For a 1,600 WCE size dairy, the incremental NPV from adding fiber separation is $\$ 3.2$ million, but the NPV from the stand-alone fiber separation technology is only $\$ 0.6$ million. Thus, the technology adds an additional \$2.6 million to total NPV compared to its stand-alone NPV. This scope effect is present for all $\mathrm{AD}$ scenarios that include fiber separation.

Separating nutrients reduced NPV slightly when combined only with fiber separation, increased NPV by $0.7-1.4$ percent when combined with AD without codigestion, but reduced 
NPV by 1.7 to 2.8 percent for AD with codigestion. However, note that the NPV for AD with codigestion and fiber and nutrient separation exceeds the NPV for AD with fiber separation but without codigestion by $\$ 4.6$ to $\$ 45.3$ million for $\mathrm{CNG}$ and $\$ 5.7$ to $\$ 55.4$ million for $\mathrm{CHP}$ at the 1,600 WCE and 15,000 WCE sizes, respectively. If government environmental agencies are concerned with the potential for nutrient over-application on a dairy from codigestion, requiring nutrient separation technology for ADs with codigestion mitigates those concerns while providing larger NPV than the most profitable scenario with no codigestion.

Unlike nutrient separation, inducing adoption of water recovery technology on dairies would require extremely large subsidies. Water recovery reduces NPV much more and in almost $1 / 3$ of scenarios results in negative NPV. Stand-alone ADs that convert methane into CNG or CHP but receive no environmental credits also have negative NPVs. Only one other scenario has negative NPV, and only for the smallest of the three herd sizes. The NPVs reveal the presence of multi-output economies of scale in all AD technology systems; those with positive NPVs not only generate higher NPVs on larger dairies but higher NPVs per WCE.

The trends for IRR reported in Table 8 are identical to those for NPV. Scenarios with largest NPV have IRRs that far exceed a capital reinvestment discount rate of seven percent. Of scenarios with positive NPV, five have an IRR that is below seven percent. We also computed MIRR for each technology system using a capital reinvestment discount rate of 7 percent. MIRR accounts for reinvestment of returns and dampens rates compared to the IRR. Trends remain the same with the highest rate of return calculated to be 10 to 14 percent compared to 23 to 48 percent for IRR. MIRR results are available upon request.

Table 8. Twenty year IRR by scenario and herd size (WCE)

$\begin{array}{llll}\text { Scenario combination } & 1,600 & 4,500 & 15,000\end{array}$




\begin{tabular}{lrrr}
\hline AD, CNG & $<-100 \%$ & $<-100 \%$ & $-18 \%$ \\
AD, CNG, CNGEC & $9 \%$ & $20 \%$ & $27 \%$ \\
AD, CO, CNG, CNGEC & $18 \%$ & $31 \%$ & $38 \%$ \\
FS, AD, CNG, CNGEC & $16 \%$ & $31 \%$ & $41 \%$ \\
FS, AD, CO, CNG, CNGEC & $23 \%$ & $39 \%$ & $48 \%$ \\
FS, NS, AD, CNG, CNGEC & $15 \%$ & $25 \%$ & $31 \%$ \\
FS, NS, AD, CO, CNG, CNGEC & $20 \%$ & $32 \%$ & $37 \%$ \\
FS, NS, WR, AD, CNG, CNGEC & $5 \%$ & $10 \%$ & $12 \%$ \\
FS, NS, WR, AD, CO, CNG, CNGEC & $9 \%$ & $14 \%$ & $16 \%$ \\
AD, CHP & $-10 \%$ & $-6 \%$ & $-2 \%$ \\
AD, CHP, CHPEC & $2 \%$ & $8 \%$ & $11 \%$ \\
AD, CO, CHP, CHPEC & $17 \%$ & $28 \%$ & $33 \%$ \\
FS, AD, CHP, CHPEC & $12 \%$ & $22 \%$ & $27 \%$ \\
FS, AD, CO, CHP, CHPEC & $24 \%$ & $37 \%$ & $43 \%$ \\
FS, NS, AD, CHP, CHPEC & $11 \%$ & $18 \%$ & $21 \%$ \\
FS, NS, AD, CO, CHP, CHPEC & $20 \%$ & $29 \%$ & $33 \%$ \\
FS, NS, WR, AD, CHP, CHPEC & $0 \%$ & $3 \%$ & $4 \%$ \\
FS, NS, WR, AD, CO, CHP, CHPEC & $8 \%$ & $11 \%$ & $12 \%$ \\
FS & $24 \%$ & $24 \%$ & $24 \%$ \\
FS, NS & $10 \%$ & $10 \%$ & $10 \%$ \\
FS, NS, WR & $-100 \%$ & $<-100 \%$ & $<-100 \%$ \\
\hline N
\end{tabular}

Notes: AD: anaerobic digester; CNG: compressed natural gas; CNGEC: CNG environmental credits; CO: codigest organics; CHP: combined heat and power; CHPEC: CHP environmental credits; FS: fiber separation; NS: nutrient separation; and WR: water recovery.

Construction grants have been frequently used to induce construction of AD systems. We examine the percent construction grants that would be needed to produce the same NPV as the most profitable $\mathrm{AD}$ system if regulations required nutrient separation or water recovery to be part of the system. Grants covering 4-7 percent of total capital costs would be sufficient if nutrient separation were required, but much larger grants (82-117 percent) would be needed to generate the same NPV if both nutrient separation and water recovery were required.

The specific results of this paper apply most directly to Washington State, but they are also relevant to other states. The broader policy implications for stimulating adoption of nutrient separation to mitigate the effects of codigestion are applicable internationally. However, the exact percent of capital costs required to induce firms to adopt an AD system with nutrient 
separation would depend on local circumstances. It is also important to recall that environmental credits have a short history and provide limited data which we use to establish a baseline. The rapid transformation of environmental markets makes forecasted future markets highly uncertain.

We examine the effects of altering the prices of environmental credits in a brief sensitivity analysis. If the AD project is able to qualify for LCFS credits (in the case that California is geographically close), NPV increases by $\$ 0.2$ million for the no-codigestion cases and $\$ 0.4$ million for codigestion cases for 1,600 WCE dairies and by $\$ 2.2$ million for nocodigestion cases and $\$ 3.8$ million for codigestion cases for 15,000 WCE dairies. Depending on the scenario, these increases would range from 3 to 37 percent of NPV. If RIN price decreases by 50 percent, NPV for CNG scenarios decreases by $\$ 2.9$ million for no-codigestion cases and $\$ 3.7$ million for codigestion cases for 1,600 WCE dairies and by $\$ 26.9$ million for no-codigestion cases and $\$ 34.9$ million for codigestion cases for 15,000 WCE dairies. Depending on the scenario, these decreases would range from 30 to 445 percent of NPV. If carbon, REC, and tax credit prices all decrease by 50 percent, NPV for CHP scenarios decreases by $\$ 0.9$ million for the no-codigestion cases and $\$ 1.6$ million for codigestion cases for 1,600 WCE dairies and by $\$ 8.7$ million for no-codigestion and $\$ 15.2$ million for codigestion cases for 15,000 WCE dairies. Depending on the scenario, these decreases would range from 16 to 1,616 percent of NPV.

\section{Conclusions}

US dairy trade groups (e.g., the Innovation Center for US Dairy) and US governmental organizations (like the EPA's program AgSTAR) have promoted the widespread adoption of AD as a partial solution to pollution concerns surrounding large dairy operations. Unfortunately, one of the most profitable components of an AD on a US dairy—codigestion — has the potential to lead to greater water pollution from excess $\mathrm{N}$ and $\mathrm{P}$. This paper explores the economic viability 
of technology combinations within an integrated $\mathrm{AD}$ system to mitigate both GHG and water pollution.

The most profitable AD scenarios include codigestion of off-farm organic wastes, due primarily to tipping fees for accepting waste but also to increased methane output. However, the additional organic waste contributes to nutrient over-application and necessitates increased land availability for nutrient disposal or alternative management of nutrients. Energy production from extracted methane also contributes substantially to AD system profitability. Compressed natural gas $(\mathrm{CNG})$ is generally a more valuable use of the methane than combined heat and power (CHP) because of current differences in environmental credit values. Environmental credits have the potential to produce large increases in NPV. Fiber separation also increases NPV but not as much as codigestion or energy production (with corresponding environmental credits).

Integrated AD systems that include nutrient separation generally produce positive NPVs when combined with energy creation and fiber separation, but it modestly decreases overall NPV with codigestion. Water recovery technology is currently sufficiently expensive to plunge NPV into the negative range for nearly half of the scenarios that include it.

As previous literature documents, farmers have the incentive to over-apply nutrients to near fields due to transportation cost when there is no direct oversight. This is especially important in light of the large value that codigestion brings to an $\mathrm{AD}$ project and the additional nutrients that codigestion adds. Although nutrient separation leads to an overall decrease in the NPV of the project, policy makers can encourage adoption of this technology through targeted grants or minor regulations. The NPV of AD codigestion systems with nutrient and fiber separation far exceeds the NPV of AD systems without codigestion and nutrient separation. 
Thus, requiring nutrient separation technology for ADs that accept off-farm organic waste can mitigate nutrient over-application concerns while enabling an investment that is at least as viable.

As expected, we found evidence of economies of scale in AD systems, even over the range of very large dairies we considered. We also found economies of scope when combining technologies into an integrated AD system. Our findings are important to the US dairy industry and environmental regulators. Our method of economic evaluation of integrated technologies using engineering functions to structurally model complementary effects may also prove useful for examining adoption of other potentially complementary technological processes. 


\section{References}

AgSTAR. 2016. “AgSTAR Database of Livestock Digesters.” Washington DC: U.S. Environmental Protection Agency. Available at: http://www2.epa.gov/agstar/livestockanaerobic-digester-database (accessed June 27, 2016).

---. 2011. "Market Opportunities for Biogas Recovery Systems at U.S. Livestock Facilities." Washington DC: U.S. Environmental Protection Agency, November.

Aldy, J.E., and R.N. Stavins. 2012. "The Promise and Problems of Pricing Carbon: Theory and Experience." The Journal of Environmental \& Development 21(2): 152-180.

Appels, L., J. Lauwers, J. Degrève, L. Helsen, B. Lievens, K. Willems, J. Van Impe, and R. Dewil. 2011. "Anaerobic Digestion in Global Bio-energy Production: Potential and Research Challenges.” Renewable and Sustainable Energy Reviews 15(9):4295-4301.

Argus Media. 2014. "California Environmental Markets: Factors that Affect LCFS and GHG Trading.” Argus White Paper. Houston, Texas.

American Society of Agricultural Engineers. 2005. "Manure Production and Characteristics." American Society of Agricultural Engineers Standard. St. Joseph, Michigan.

Atandi E., and S. Rahman. 2012. "Prospect of Anaerobic Co-digestion of Dairy Manure: A Review.” Environmental Technology Reviews 1(1): 127-135.

Bishop, C.P., and C.R. Shumway. 2009. "The Economics of Dairy Anaerobic Digestion with Coproduct Marketing." Review of Agricultural Economics 31(3): 394-410.

Braun, R., E. Brachtl, and M. Grasmug. 2003. "Codigestion of Proteinaceous Industrial Waste." Applied Biochemistry and Biotechnology 109: 139-153.

Britz, W., and R. Delzeit. 2013. "The Impact of German Biogas Production on European and Global Agricultural Markets, Land Use and the Environment.” Energy Policy 62: 12681275.

California Air Resources Board. 2015. "Draft, Short-lived Climate Pollutant Reduction Strategy." Sacramento, California.

California Carbon Dashboard. 2015. "Price of California Carbon Allowance Futures." ICE End of Day Reports. Available at: http://calcarbondash.org/ (accessed September 23, 2015).

Camarillo, M.K., W.T. Stringfellow, C.L. Spier, J.S. Hanlon, and J.K. Domen. 2013. "Impact of Co-digestion on Existing Salt and Nutrient Mass Balances for a Full-scale Dairy Energy Project." Journal of Environmental Management 128: 233 - 242.

Camarillo, M.K., W.T. Stringfellow, M.B. Jue, and J.S. Hanlon. 2012. "Economic Sustainability of a Biomass Energy Project Located at a Dairy in California, USA." Energy Policy 48: 790-798. 
Camberato, J. and R.L. Nielsen. 2015. "Nitrogen Management Guidelines for Corn in Indiana." Applied Crop Research Update, February. Purdue University. Available at: http://www.kingcorn.org/news/timeless/NitrogenMgmt.pdf (accessed October 1, 2015).

Carbon Washington. 2015. "Cleaner Energy. Fairer Taxes." Available at: www.carbonwa.org (accessed October 1, 2015).

Chiumenti, A., F. Da Borso, F. Teri, R. Chiumenti, and B. Piaia. 2013. "Full-scale Membrane Filtration System for the Treatment of Digestate from a Co-digestion Plant." Applied Engineering in Agriculture 29(6): 985-990.

Coppedge, B., G. Coppedge, D. Evans, J. Jensen, E. Kanoa, K. Scanlan, B. Scanlan, P. Weisberg, and C. Frear. 2012. "Renewable Natural Gas and Nutrient Recovery Feasibility for DeRuyter Dairy.” Report prepared for Washington State Department of Commerce: Olympia, Washington.

Corominas, L., H.F. Larsen, X. Flores-Alsina, and P.A. Vanrolleghem. 2013. "Including Life Cycle Assessment for Decision-making in Controlling Wastewater Nutrient Removal Systems." Journal of Environmental Management 128: 759-767.

Council for Agricultural Science and Technology. 2002. "Animal Diet Modification to Decrease the Potential for Nitrogen and Phosphorus Pollution” Issue Paper, Number 21. Ames, Iowa.

Cowley, C. 2014. "Economic and Political Considerations for Anaerobic Digestion Technology Adoption on Animal Feeding Operations." Survey Data Summary. Personal Communication.

Demirel, B., Scherer, P., 2008. "Production of Methane from Sugar Beet Silage without Manure Addition by a Single-stage Anaerobic Digestion Process." Biomass and Bioenergy 32: 203-209.

ECOregon. 2010. “Oregon Dairy Digester Feasibility Study Summary Report.” Seattle, Washington: Northwest Dairy Association, January 25.

Elgie, S., and J. McClay. 2013. "BC's Carbon Tax Shift is Working Well after Four Years (Attention Ottawa)." Canadian Public Policy 39: S1-S10.

Erisman, J.W., and M. Schaap. 2004. "The Need for Ammonia Abatement with Respect to Secondary PM Reductions in Europe.” Environmental Pollution 129(1): 159-163.

Executive Office of Energy and Environmental Affairs of the Commonwealth of Massachusetts. 2015. "Commercial Food Waste Disposal Ban." Boston, Massachusetts. Available at: http://www.mass.gov/eea/agencies/massdep/recycle/reduce/food-waste-ban.html (accessed June 29, 2015).

Federal Reserve Economic Data. 2016. Moody’s Seasoned BAA Corporate Bond Yield. Available at: http://research.stlouisfed.org/fred2/series/BAA (accessed Sep. 20, 2016). 
Frear, C. 2015. "Fiber Separation Characteristics and Prices." Personal Communication. Regenis: Ferndale, Washington.

Gerber, P.J., H. Steinfeld, B. Henderson, A. Mottet, C. Opio, J. Dijkman, A. Falculli, and G. Tempio. 2013. "Tackling Climate Change Through Livestock: A Global Assessment of Emissions and Mitigation Opportunities." United Nations, Food and Agricultural Organization (FAO), Rome.

Glover, T. 1996. “Livestock Manure: Foe or Fertilizer?” Agricultural Outlook, U.S. Department of Agriculture, Economic Research Service (June): 30-35.

Gloy, B.A. 2011. "The Potential Supply of Carbon Dioxide Offsets from the Anaerobic Digestion of Dairy Waste in the United States." Applied Economic Perspectives and Policy 33(1): 59-78.

Halpern, D. 2013. "Low Cost Nutrient Recovery for Improved Project Profitability." Anaerobic Digestion and Biogas Conference, 17 May. Thermoenergy: Worcester, Massachusetts.

Harrigan, T. 2011. "Economics of Liquid Manure Transport and Land Application." Michigan Dairy Review 16(4), October. Michigan State University.

Henricks, M. 2014. "More States Ban Organic Waste in Landfills.” American Recycler News, Inc: Perrysburg, Ohio. Available at: http://www.americanrecycler.com/0114/2428more.shtml (accessed October 1, 2015).

Huang, W., R. Magleby, and L. Christensen. 2005. "Economic Impacts of EPA's Manure Application Regulations on Dairy Farms with Lagoon Liquid Systems in the Southwest Region." Journal of Agricultural and Applied Economics 37(1): 209-227.

Informa Economics. 2013. "National Market Value of Anaerobic Digester Products.” Report prepared for Innovation Center for US Dairy, February. Available at: http://www.usdairy.com/ /media/usd/public/nationalmarketvalueofanaerobicdigesterprod ucts.pdf.pdf (accessed October 1, 2015).

Innes, R. 2000. "The Economics of Livestock Waste and Its Regulation.” American Journal of Agricultural Economics 82(1): 97-117.

Juergens, K. and E. Powell. 2014. "Digester Economics Breakout.” Unpublished Excel Spreadsheet. Andgar Corporation: Ferndale, Washington.

Key, N. and S. Sneeringer. 2012. "Carbon Emissions, Renewable Electricity, and Profits: Comparing Policies to Promote Anaerobic Digesters on Dairies." Agricultural and Resource Economics Review 41(2): 139-157.

Kiely, G. 1997. Environmental Engineering. London: McGraw-Hill. 
Klavon, K.H., S.A. Lansing, W. Mulbry, A.R. Moss, and G. Felton. 2013. "Economic Analysis of Small-scale Agricultural Digesters in the United States." Biomass and Bioenergy 54: $36-45$.

Lebuhn, M., B. Munk, and M. Effenberger. 2014. "Agricultural Biogas Production in Germany From Practice to Microbiology Basics.” Energy, Sustainability and Society 4(1): 1-21.

Leuer, E.R., J. Hyde, and T.L. Richard. 2008. "Investing in Methane Digesters on Pennsylvania Dairy Farms: Implications of Scale Economies and Environmental Programs." Agricultural and Resource Economics Review 37(2): 188-203.

Lisboa, M.S., and S. Lansing. 2013. "Characterizing Food Waste Substrates for Co-digestion through Biochemical Methane Potential (BMP) Experiments." Waste Management 33(12): 2664-2669.

Ma, J., Yu L., C. Frear, Q. Zhao, X. Li, S. Chen. 2013a. "Kinetics of Psychrophilic Anaerobic Sequencing Batch Reactor Treating Flushed Dairy Manure.” Bioresource Technology 131: 6-12.

Ma, J., N. Kennedy, G. Yorgey, and C. Frear. 2013b. "Review of Emerging Nutrient Recovery Technologies for Farm-based Anaerobic Digesters and Other Renewable Energy Systems." Report prepared for the Innovation Center for US Dairy, November 6. Washington State University.

Ma, J., and C. Frear. 2015. "Mass Balances of Processed Manure Effluent." Unpublished Excel Spreadsheet. Washington State University.

Madison, F., K. Kelling, L. Massie, and L. Ward Good. 1995. "Guidelines for Applying Manure to Cropland and Pasture in Wisconsin.” Extension Bulletin R-8-95-2M-E. University of Wisconsin-Extension.

Manning, D.T., and J.C. Hadrich. 2015. "An Evaluation of the Social and Private Efficiency of Adoption: Anaerobic Digesters and Greenhouse Gas Mitigation.” Journal of Environmental Management 154: 70-77.

Matharu, A.S., E.M. de Melo, and J.A. Houghton. 2016. "Opportunity for High Value-added Chemicals from Food Supply Chain Wastes.” Bioresource Technology 215: 123-130.

Meyer, D., I. Garnett, and J.C. Guthrie. 1997. "A Survey of Dairy Manure Management Practices in California." Journal of Dairy Science 80(8): 1841-1845.

Missouri Department of Transportation. 2008. "Freight Equivalent Units by Mode." Freight Development: Missouri's Economy in Motion.

Murray, B.C., C.S. Galik, and T. Vegh. 2014. "Biogas in the United States: An Assessment of Market Potential in a Carbon-constrained Future." Nicholas Institute Report, February. Duke University. Available at: 
http://nicholasinstitute.duke.edu/sites/default/files/publications/ni_r_14-02_full_pdf.pdf (accessed October 1, 2015)

Najafpour G.D., A.A.L. Zinatizadeh, A.R. Mohamed, M. Hasnain Isa, H. Nasrollahzadeh. 2006. "High-rate Anaerobic Digestion of Palm Oil Mill Effluent in an Upflow Anaerobic Sludge-fixed Film Bioreactor." Process Biochemistry 41: 370-9.

Natural Resources Conservation Service. 2011. National Agronomy Manual. Washington DC: U.S. Department of Agriculture, February.

New York State Energy Research and Development Authority (NYSERDA). 2015. "Renewable Portfolio Standard Customer-Sited Tier Anaerobic Digester Gas-to-Electricity." Program Opportunity Notice (PON) 2828. Albany, New York. Available at: http://www.nyserda.ny.gov/Funding-Opportunities/Current-Funding-Opportunities/PON2828-Renewable-Portfolio-Stand-Customer-Sited-Tier-Anaerobic-Digester-Gas-toElectricity (accessed Oct. 1, 2015).

Niero, M., M. Pizzol, H.G. Bruun, and M. Thomsen. 2014. "Comparative Life Cycle Assessment of Wastewater Treatment in Denmark including Sensitivity and Uncertainty Analysis." Journal of Cleaner Production 68:25-35.

Njuki, E., and B.E. Bravo-Ureta. 2015. "The Economic Costs of Environmental Regulation in U.S. Dairy Farming: A Directional Distance Function Approach.” American Journal of Agricultural Economics 97(4): 1-20.

Ontiveros, G.A., and E.A. Campanella. 2013. "Environmental Performance of Biological Nutrient Removal Processes from a Life Cycle Perspective." Bioresource Technology 150: 506-512.

Osterburg, B., and N. Röder. 2013. "Effects of Agricultural Biogas-production Facilities on Land Use and Land-use Change in Lower Saxony." Grassland Science in Europe 18: 531-533.

Painter K., and C.W. Gray. 2012. "Costs and Returns for a 2500-Head Free Stall Dairy in Southern Idaho." Excel Workbook EBB-D4-12. University of Idaho. Available at: http://web.cals.uidaho.edu/idahoagbiz/enterprise-budgets/current-cost-of-productionstudies/current-dairy-budgets/ (accessed October 1, 2015).

Palmquist, R.B., F.M. Roka, and T. Vukina. 1997. "Hog Operations, Environmental Effects, and Residential Property Values." Land Economics 73(1): 114-124.

Piao, W., Y. Kim, H. Kim, M. Kim, and C. Kim. 2016. "Life Cycle Assessment and Economic Efficiency Analysis of Integrated Management of Wastewater Treatment Plants." Journal of Cleaner Production 113: 325-337.

Plastina, A., A. Johanns, and S. Weets. 2015. "Iowa Farm Custom Rate Survey.” Ag Decision Maker. File A3-10. Extension and Outreach, Iowa State University. 
Promus Energy. 2014. "Promus Post Digestion Unit Operation Analysis.” Unpublished Excel Spreadsheet. Seattle, Washington.

Regional Greenhouse Gas Initiative. 2014. "Regional Investment of RGGI $\mathrm{CO}_{2}$ Allowance Proceeds, 2012.” New York, New York.

Ribaudo, M., N. Gollehon, M. Aillery, J. Kaplan, R. Johansson, J. Agapoff, L. Christensen, V. Breneman, and M. Peters. 2003. "Manure Management for Water Quality: Costs to Animal Feeding Operations of Applying Manure Nutrients to Land." Washington CD: U.S. Department of Agriculture, Economic Research Service, Report Number 824, June.

Rotz, C.A. 2004. "Management to Reduce Nitrogen Losses in Animal Production." Journal of Animal Science 82: E119 - E137.

Sadhukhan J., K.S. Ng, E. Martinez-Hernandez. 2016. "Novel Integrated Mechanical Biological Chemical Treatment (MBCT) Systems for the Production of Levulinic Acid from Fraction of Municipal Solid Waste: A Comprehensive Techno-economic Analysis." Bioresource Technology 215: 131-43.

Sadhukhan J. 2014. "Distributed and Micro-generation from Biogas and Agricultural Application of Sewage Sludge: Comparative Environmental Performance Analysis Using Life Cycle Approaches." Applied Energy 122: 196-206.

Sadhukhan J., Y. Zhao, M. Leach, N.P Brandon, and N. Shah. 2010a. "Energy Integration and Analysis of Solid Oxide Fuel Cell Based Micro-CHP and Other Renewable Systems Using Biomass Waste Derived Syngas." Industrial \& Engineering Chemistry Research 49(22): 11506-16.

Sadhukhan J., Y. Zhao, N. Shah, N.P. Brandon. 2010b. "Performance Analysis of Integrated Biomass Gasification Fuel Cell (BGFC) and Biomass Gasification Combined Cycle (BGCC) Systems.” Chemical Engineering Science 65: 1942-54.

Sadhukhan J., K.S. Ng, N. Shah, H.J. Simons. 2009. "Heat Integration Strategy for Economic Production of Combined Heat and Power from Biomass Waste." Energy \& Fuels 23: 5106-20.

Sanford, G.R., J.L. Posner, and G.L. Hadley. 2009. "Economics of Hauling Dairy Slurry and its Value in Wisconsin Corn Grain Systems." Journal of Agricultural, Food, and Environmental Sciences 3(1): 1-10.

Schmit, T.M., and W.A. Knoblauch. 1995. "The Impact of Nutrient Loading Restrictions on Dairy Farm Profitability.” Journal of Dairy Science 78(6): 1267-1281.

Schwarz, M., J. Bonhotal, and A.E. Staehr. 2010. "Use of Dried Manure Solids as Bedding for Dairy Cows.” Cornell Waste Management Institute. Cornell University. 
Scott, N. and J. Ma. 2004. "A Guideline for Co-digestion of Food Wastes in Farm-based Anaerobic Digesters." Cornell Manure Management Program, Cornell Cooperative Extension, December.

Shiller, R.J. 2015. Long Term Stock, Bond, Interest Rate and Consumption Data. Available at: http://www.econ.yale.edu/ shiller/data.htm (accessed Sep. 20, 2016).

Smith, P., D. Martino, Z. Cai, D. Gwary, H. Janzen, P. Kumar, B. McCarl, S. Ogle, F. O’Mara, and C. Rice. 2007. "Climate Change 2007: Mitigation. Contribution of Working Group III to the Fourth Assessment Report of the Intergovernmental Panel on Climate Change." Cambridge: Cambridge University Press.

Terre-Source. 2003. "Study to Evaluate the Price and Markets for Residual Solids from a Dairy Cow Manure Anaerobic Digester." Report prepared for King County, Solid Waste Division: Seattle, Washington.

The Prasino Group and Innovation Center for U.S. Dairy. 2014. "Resource Recovery for the U.S. Dairy Industry.” Report prepared for Dairy Management Inc. and National Milk Producers Federation, May 29.

US Composting Council. 2014. "States that Ban Organics or Mandate Organics RecyclingOctober 2014.” Bethesda, Maryland. Available at: http://compostingcouncil.org/?attachment_id=21838 (accessed October 22, 2014).

U.S. Department of Agriculture, National Agricultural Statistics Service. 2012. 2012 Census of Agriculture. Washington DC.

U.S. Environmental Protection Agency. 2016. Landfill Methane Outreach Program: Operational Projects. Available at: https://www3.epa.gov/lmop/projects-candidates/operational.html (accessed August 26, 2016).

---. 2014a. "Inventory of U.S. Greenhouse Gas Emissions and Sinks: 1990-2012." Chapter 4. Executive Summary: ES1 - ES27. Washington DC.

---. 2014b. "National Summary of State Information. Water Quality Assessment." Washington DC. Available at: http://iaspub.epa.gov/tmdl_waters10/attains_index.home (accessed Oct. $1,2015)$.

Van Breeman, N., and H.F. Van Dijk. 1988. "Ecosystem Effects of Atmospheric Deposition of Nitrogen in the Netherlands." Environmental Pollution 54(3-4): 249-74.

Van Horn, H.H., A.C. Wilkie, W.J. Powers, and R.A. Nordstedt. 1994. "Components of Dairy Manure Management Systems.” Journal of Dairy Science 77(7): 2008-2030.

Washington State Department of Health (WS-DOH). 2005. "Nitrogen Reducing Technologies for Onsite Wastewater Treatment Systems". Report prepared for the Puget Sound Action Team. DOH Publication 337-093, June. 
Water Environment Federation. 2015. Biogas Data. Available at: http://www.resourcerecoverydata.org/biogasdata.php (accessed August 26, 2016).

Weisberg, P. 2015. Personal communication. The Climate Trust: Portland, Oregon.

---. 2014. "Biogas Projects Qualify as Cellulosic Fuel under the Renewable Fuel Standard." The Climate Trust: Portland, Oregon. Available at: https://www.climatetrust.org/biogasprojects-qualify-as-cellulosic-fuel-under-the-renewable-fuel-standard/ (accessed September 28, 2015).

---. 2013. "Environmental Markets and Biogas: Valuing Climate Benefits." EPA 2013 AgSTAR National Conference. The Climate Trust: Portland, Oregon.

---. 2012. “Environmental Market Revenue Opportunities for Biogas Projects.” NEBC NW Biogas Workshop. The Climate Trust: Portland, Oregon.

Wilkinson, K.G. 2011a. "A Comparison of the Drivers Influencing Adoption of On-farm Anaerobic Digestion in Germany and Australia." Biomass and Bioenergy 35(5): 16131622.

---. 2011b. Development of On-Farm Anaerobic Digestion, Integrated Waste Management Volume I. M. S. Kumar, ed. Rijeka, Croatia: Intech.

Wright, P.E., S. Inglis, J. Ma, C. Gooch, B. Aldrich, and N. Scott. 2004. "Preliminary Comparison of Five Anaerobic Digestion Systems on Dairy Farms in New York State." ASAE/CSAE International Meeting, Ottowa Canada, 1-4 August.

Yorgey, G., C. Frear, J. Ma, and N. Kennedy. 2015. "Approaches to Nutrient Recovery from Dairy Manure." Extension Bulletin (unpublished). Washington State UniversityExtension.

Zhang, W. and R. Parsons. 2001. "Financial Impacts of Alternative Phosphorus Management Practices: The Case of Vermont Dairy Farms.” AAEA annual meeting, Chicago, Illinois. 